\title{
RICE PADDY FARMERS' PERCEPTIONS ON THE PERFORMANCE OF AGRICULTURAL EXTENSION OFFICERS (AEOS) SERVING THE TARA-TARA III VILLAGE, TOMOHON CITY, NORTH SULAWESI PROVINCE, INDONESIA
}

\author{
Olfie L.S. Benu*, Welson M. Wangke \\ Department of Social Economics, Faculty of Agriculture, Sam Ratulangi University, \\ Manado, Indonesia \\ *E-mail: olfiebenu01@gmail.com
}

\begin{abstract}
We have conducted a study to survey the perceptions of rice farmers on the role and performance of agricultural extension officers in the Village of Tara-Tara III, Tomohon City, North Sulawesi Province, which is one of rice production centers in Tomohon. 20 respondents were selected randomly. The primary data were obtained from interview for three months using a list of prepared questions. The secondary data were obtained from the BP3K Office of the Tomohon City and Tara-Tara III Village Office. The variables measured in this study were the outreach programs, action plans, maps of the area of technology development, dissemination of new technology information, access to financial institutions and farmers' income. The analysis was performed descriptively using tables. The results show that the agricultural extension officers (AEOs) did not yet provide tangible benefits to the farmers. The roles of the officers were considered merely as a transfer of technology and information. While the farmers expected them to function as a problem solver, a motivator and a facilitator. Such roles are required to deal with the dynamic changes in farmer's daily life and to fulfill the mission of agricultural extension, e.g. development of farmer's independence.
\end{abstract}

\section{KEY WORDS}

Farmers' perception, Agricultural Extension Officers performance, rice paddy, Tomohon, North Sulawesi.

Counseling is an effort undertaken as a process of learning to encourage changes in behavior at the individual, group, community, or society levels so that they understand, willing and able to help and organize themselves in accessing market information, technology, capital, and other resources, in an effort to improve productivity, business efficiency, capitals, and welfare, as well as to raise awareness of the environment conservation (Röling, 1985; Oakley, 1988).

Counseling activities involve at least five aspects, namely: (1) the learning process, (2) the learning subjects, (3) development of self-awareness and capacity, (4) resource management for life improvement, and (5) implementation of the principle of sustainability in terms of social economic and implementation of environmental sustainability function (Slamet, 2002). There also are three main objectives of agricultural extension, i.e. helping farmers to improve their business and higher income, helping farmers to improve their life and helping farmers to develop their life (Chamala, 1987).

One important element in agricultural extension is the people who carry out the job. The officer directly works with farmers and carries out the consultation to identify problems faced by the farmers and help solving them. To reach the counseling purposes, good professional qualified extension personnels are needed (Baillie, 1984).

Along with the rapidly development of science and technology and flow of information that are more easily accessible, therefore an extension officer must always improve and update his/her knowledge. In addition, the extension officers are expected to well perform in carrying out consultation and counselling tasks for the purpose of the development of agriculture (Chambers et al., 1989). In practice, the performance of agricultural extension officers (AEOs) is affected by various factors both internally and externally. Internal factors 
are age, education level and years of service of the officers, while the external factors are, for instance, the availability of facilities and infrastructure, reward systems, as well as dwelling for the officers. Normally, the job in one village is handled by one officer.

According to Kartasapoetra (1988), there are three roles performed by an agricultural extension officer, namely:

1. A role as an educator who provides new knowledge or technique in the cultivation of crops, so that farmers are more focused on their farming, to improve production and to avoid failures in farming.

2. A role as a leader who guides and motivates the farmers to change the way of thinking and how they work to arise openness and willingness to implement new techniques of farming that is more efficient and effective, so to have more prosperous life.

3. A role as an advisor who serves and gives guidance and assists farmers in demonstration or gives examples of work in farming and to solve any problems faced by the farmers.

This manuscript presents the results of our study in surveying the performance of agricultural extension officers from the standpoint of farmers's perception in the study area in an effort to support the achievement of self-sufficiency in rice production in North Sulawesi province.

\section{MATERIALS AND METHODS}

The research was conducted in the Village of Tara-Tara III, District of Western Tomohon, the City of Tomohon, North Sulawesi Province, which is one of the centers of rice production in Tomohon. The respondents were selected randomly as many as 20 persons (16 males and 4 females) from 112 farmers in the village. Data were obtained by interview for three months from a list of prepared questions. The secondary data were obtained from the BP3K Office of the District of Western Tomohon and Tara-Tara Village III Office. The variables measured in this study were outreach programs, action plans, maps of the area of technology development, dissemination of new technology information, access to financial institutions and farmers' income. The data were displayed in histograms and the analysis was performed descriptively.

\section{RESULTS AND DISCUSSION}

Description of Respondents. Most of the respondents (70\%) had high schools education (grade 7-12), while only 1 (5\%) had a university degree and $25 \%$ were only graduated from primary schools. Majority of the farmers had more than 20 years experience in farming (Table 1). Education level and experience influence the farmer's background knowledge and ability to comprehend the lessons when come to apply what they have learned from the extension programs.

Farmer group is a very important forum for distribution of agricultural related information and innovations. An active member will receive updated information and dynamic agricultural innovations. $60 \%$ of our respondents are members of a local farmer group with moderate to active involvement in the extension programs.

Majority of the respondents work in smaller crop land of less than half of a hectare $(65 \%)$ and the rest of $35 \%$ work in larger crop field. This is what may lead to the income generated by majority of the farmer (65\%) were less than IDR $1,000,000$ per month.

Farmers Perception of the AEOs Performance. Rice farmer' perceptions on the performance of Agricultural Extension Workers serving them are summarized as follows (see Table 2).

Suitability of the Extension Programs. The education programs planned by the Extension Officers should fulfill the needs of farmers, so they will adopt the information delivered by the Officers. For a question on suitability of the extension programs with the needs of the farmers, majority of respondents indicated that the extension programs delivered fitted their needs. There were two respondents who stated otherwise. They did not 
satisfy with the programs due to difficulty in the implementation, such as credit application. The remaining five respondents claimed not to know because they were not active in activities. In general, there was no tendency of farmers to reject any new innovations recommended by Extension Officers.

Table 1 - Socio-economic characteristics of the respondents $(n=20)$

\begin{tabular}{|c|c|c|c|}
\hline \multirow{2}{*}{\multicolumn{2}{|c|}{ Categories of farmers }} & \multicolumn{2}{|c|}{$\begin{array}{l}\text { No. } \\
\text { respondents }\end{array}$} \\
\hline & & Male & Female \\
\hline \multirow{3}{*}{ Age } & $<40$ years & 3 & 1 \\
\hline & $41-50$ years & 4 & 1 \\
\hline & $>50$ years & 9 & 2 \\
\hline \multirow{4}{*}{ Education } & University & 1 & 0 \\
\hline & Senior High School (grade 10-12) & 4 & 1 \\
\hline & Junior High School (grade 7-9) & 8 & 1 \\
\hline & Primary School (grade 1-6) & 3 & 2 \\
\hline \multirow{3}{*}{ Experience in Farming } & $<20$ years & 4 & 1 \\
\hline & $20-30$ years & 8 & 1 \\
\hline & $>30$ years & 4 & 2 \\
\hline \multirow{2}{*}{ Farmer Group Membership } & Member & 11 & 1 \\
\hline & Non Member & 5 & 3 \\
\hline \multirow{3}{*}{$\begin{array}{c}\text { Active Involvement in Agricultural Extension } \\
\text { Programs }\end{array}$} & Active & 4 & 1 \\
\hline & Moderate & 7 & 2 \\
\hline & Not Active & 3 & 1 \\
\hline \multirow{3}{*}{ Area of Agriculture Land } & $<0.5$ hectare & 11 & 2 \\
\hline & $0.5-1.0$ hectare & 3 & 1 \\
\hline & $>1.0$ hectare & 2 & 1 \\
\hline \multirow{2}{*}{ Land Ownership Status } & Owner & 10 & 2 \\
\hline & Rent/Worker & 6 & 2 \\
\hline \multirow{3}{*}{ Family Income (per month) } & $<$ IDR 500,000 (USD 50 equiv.) & 1 & 2 \\
\hline & IDR $500,000-1,000,000$ (USD $50-100$ & 9 & 1 \\
\hline & $>$ IDR $1,000,000$ (USD 100 equiv.) & 6 & 1 \\
\hline
\end{tabular}

Table 2 - Summary of farmers answers to survey questionnaire

\begin{tabular}{|c|c|c|c|c|c|c|c|c|c|c|c|c|c|c|c|c|c|c|}
\hline 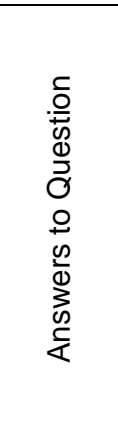 & 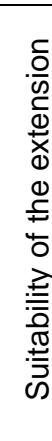 & & 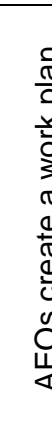 & & 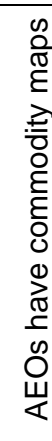 & & 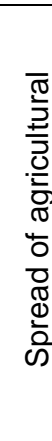 & & 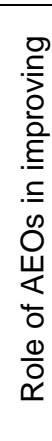 & & 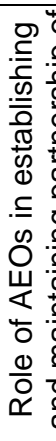 & 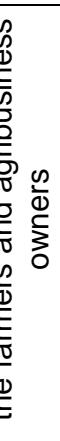 & 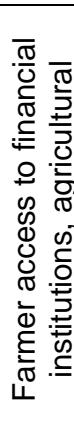 & 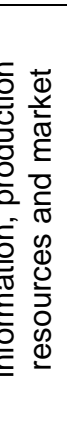 & 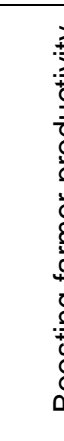 & & 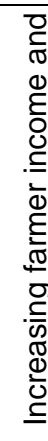 & \\
\hline- & $\mathrm{M}$ & $\mathrm{F}$ & $\mathrm{M}$ & $F$ & $\mathrm{M}$ & $\mathrm{F}$ & $\mathrm{M}$ & $F$ & $M$ & $\mathrm{~F}$ & $M$ & $\mathrm{~F}$ & $\mathrm{M}$ & $\mathrm{F}$ & $\mathrm{M}$ & $\mathrm{F}$ & $M$ & $\mathrm{~F}$ \\
\hline Yes & 8 & 5 & 8 & 5 & 9 & 5 & 9 & 5 & 10 & 4 & 9 & 2 & 10 & 3 & 7 & 2 & 10 & 2 \\
\hline No & 1 & 1 & 1 & 1 & 1 & 1 & 3 & 1 & 3 & 1 & 1 & 3 & 3 & 2 & 1 & 2 & 1 & 2 \\
\hline $\begin{array}{l}\text { Do not } \\
\text { know }\end{array}$ & 2 & 3 & 3 & 2 & 4 & 2 & 1 & 1 & 1 & 1 & 4 & 1 & 1 & 1 & 3 & 2 & 3 & 2 \\
\hline
\end{tabular}

The Extension Officers Create a Work Plan. Respondents' perception of the performance of Agricultural Extension Officers related to the presence or absence of extension work plan also is presented. Most of the respondents agreed that the extension officer referred to a work plan in implementing their activities. Respondents who answered 'do not know' were those who were not active or never attended in such activities.

The Extension Officers Have Commodity Maps and Zones. The availability of maps of agricultural potentials of a region will help the extension officers in their job. In this regard, 
most respondents stated that the Officer working with them posses zoning maps of their work area and commodity.

Spread of Agricultural Technology. The spread of agricultural technology among the farmers cannot be separated from the Agricultural Extension Officers activities. Most respondents acknowledged that the Officer has succesfully carried out his duty in introducing farming technologies to the farmers.

Role of AEOs in Improving Farmers' Competitiveness and Independence. One task of Agricultural Extension Officers is to strive for farmers competitive in farming that results in farmers' independence. Most respondents acknowledged that the Officer has facilitated them in gaining farming competitiveness and independence.

Role of AEOs in Establishing and Maintaining Partnership of the Farmers and Agribusiness Owners. One task of Agricultural Extension Officers is to bridge and build partnership between the farmers and the agribusiness entrepreneurs. In this aspect, most respondents stated that there were officer's attempts to foster business partnerships between farmers with agribusiness entrepreneurs. Four respondents said no attempt was made because they never received business partnerships coaching and have no business partner. Only few responents said they did not know of such effort.

Farmer Access to Financial Institutions, Agricultural Information, Production Resources and Market. Access to information providers on agricultural technology is urgently needed by farmers to develop and improve their farming business. Access availability to financial institutions (banks and non-banks) will also help farmers in financing their farm. It is also true that access to agricultural production resources is very important for farmers to increase production. Most respondents said that they were aware of the attempts made by the Officer in opening access for farmers to financial institutions, such as Bank Rakyat Indonesia, and agricultural distributors.

Boosting Farmer Productivity. With their implrmrnted programs, Agricultural Extension Officers are expected to increase farm productivity. In Tara Tara III Village most respondents stated that their farm productivity increased due to the AEO coaching.

Increasing Farmer Income and Welfare. In line with increased productivity, the farmers' income and welfare also increased. Most respondents realized and agreed that their income and welfare have increased by involving in extension programs.

Respondents Suggestions. We summarized some suggestions of respondents with regard to the performance of Agricultural Extension Officers who work in the Tara-Tara Village III as follows:

1. The AEOs should routinely visit the field to oversee the problems that may arise, especially on pests and plant diseases.

2. The AEOs must apply for agricultural equipments to the Agriculture Department of Tomohon City, as farmers desperately need them. The equipments are to be distributed to farmer groups.

3. The AEOs are also expected to pay attention to and include non members of farmer groups, in any extension activities.

4. The AEOs should cooperate with farmers in solving and evaluating actual problems that arise in the field, such as pest eradication programs.

5. The AEOs should assist the farmers with providing information on how to access financial institutions to obtain soft loans to purchase agricultural equipments and other resources, as well as access to NGOs for free trainings

6. The AEOs must establish relations with village officials to establish an agriculture cooperative to better facilitate farmers with agricultural production resources, such as fertilizers, seeds, and simple tools.

\section{CONCLUSSION}

Agricultural extension officers play an important role in transfering of technology and information to the farmers. However, our study found that according to the farmer respondents the agricultural extension officer did not yet provide tangible benefits to them. 
The roles of the officers were considered merely as a transfer of technology and information. The farmers expected them to better function as a problem solver, a motivator and a facilitator.

\section{REFERENCES}

1. Baillie, B.G. 1984. The Role of Advisory Services in Educating Farmers and Other Clients. Technical Publication. Departemen of Agriculture, New South Wales. Presented at Forum "Agriculture Education-Where is it headed?", Australian Institute of Agricultural Science, University of New England, Armidale, NSW. October 1984.

2. Chamala, S. 1987. Adoption processes and extension strategies for conservation farming. In: Cornish, P.S. Pratley, J.E. (Eds.), Tillage, New Directions in Australian Agriculture. Inkata Press, Melbourne, pp. 400-419.

3. Chambers, R. Pacey, A. Thrupp, LA. (Eds.), 1989. Farmer First Farmer Innovation and Agricultural Research. Short run press, Exeter, Great Britain.

4. Kartasapoetra, A.G. 1988. Teknologi Penyuluhan Pertanian. Penebar Swadaya. Jakarta (in Indonesian).

5. Oakley, Peter. 1988. Extension and Technological Transfer: The Need for an Alternative. Hortscience, 23(3): 98-99.

6. Röling, Neits. 1985. Extension and the Development of Human Resources: The Other Tradition in Extention Education. Paper at AERC Conference Unversity of Reading. England.

7. Slamet, M. 2002. Memantapkan Posisi dan Meningkatkan Peran Penyuluh Pembangunan dalam Pembangunan. Prosiding Seminar "Pembangunan Sumberdaya Manusia Menuju Terwujudnya Masyarakat Madani”. Departemen Pertanian (in Indonesian). 